\title{
Common partridge (Perdix perdix L.) in agrolandscapes of Central Ukraine: population dynamics and environmental implications
}

\author{
V.P. Novytskyi ${ }^{1}$, V.M. Kondratiuk ${ }^{2}$, M.S. Gruntkovskyi ${ }^{2}$, S.M. Gryshchenko ${ }^{2}$, \\ N.P. Hryshchenko ${ }^{2}$, I.S. Mytyay ${ }^{2}$ \\ ${ }^{1}$ Bila Tserkva National Agrarian University, Ukraine \\ ${ }^{2}$ National University of Life and Environmental Sciences of Ukraine \\ *Corresponding author E-mail: oomit99@ukr.net \\ Received: 14.10.2020. Accepted 25.11.2020
}

The analysis of the common partridge number dynamics during the first 15 years of the XXI century testified to its moderately fluctuating type with a tendency to dynamic reduction from 2000 to 2007. During the next 7-year period, there was a certain stabilization of the local population, which formed the lower plateau of indices within the range from 3.72 to 4.77 thousand individuals in 2007 and 2014, respectively. A 4-year cyclicity in changes of the local partridge cenopopulation dynamics was revealed. In general, 1-4 years of recession were followed by 1-2 years of relatively insignificant rise. It is worth noting, almost every subsequent peak did not reach the level of previous ones. The amplitude of fluctuations between the maximum (10.65 thousand specimens) and minimum (3.72 thousand specimens) values of the calculated birds in the regional lands was 6.94 thousand specimens, or $65.1 \%$ of the maximum. The mean density of birds in the lands during the study period was only $2.3 \pm 0.03$ birds/thousand ha, with fluctuations from 5.3 to 1.8 birds/thousand ha. The duration of the period between the maximum (2000) and minimum (2007) numbers was 7 years, and the mean number for the study period was $4.63 \pm 0.057$ thousand birds in the total area of over 2,018 thousand ha. At that time, during the study period, the upper population plateau was not recorded at all. Such changes are most likely due to the high degree of "predation" of the common fox, mass poaching, weak biotechnical measures, unsatisfactory natural fodder base in critical periods of the year and non-compliance with agricultural standards by farmers.

Key words: partridge, ecological factors, dynamics, environment, birds.

\section{Introduction}

Since 2014, Ukraine has topped the international anti-rating with the highest percentage of plowing on the planet, which at that time was, according to official data, $56.1 \%$ of its territory; including plowing of agricultural lands that amounted here to $78.8 \%$ (Pyrozhok, 2018). The consequence of the high plowing level was the degradation of Ukrainian soils, development of desertification processes and the loss of faunal diversity in agrolandscapes, in particular, due to monocropping focused on growing large areas of "export" industrial tall crops - corn and sunflower. These circumstances prompted us to study environmental aspects of the common partridge's (Perdix perdix Linnaeus, 1758) life-sustaining activity, as a indicator game species recommended to assess the ecological status of agricultural landscapes in Ukraine (Fedyushko, 2011).

\section{Material and methods}

We used statistical reporting data selected for Vinnytsia region, which is located in the middle of Ukraine and is one of the developed agrarian region in Central Ukraine. Agricultural lands make here $76.1 \%$ of the regional area (Ushkalenko, 2018). To form an analytical sample of the common partridge population and environmental factors, we used data obtained from annual statistical collections "Environment of Ukraine", statistical yearbooks of Vinnytsia region, amd indices of state statistical reporting forms "2-tp (hunting)", prepared during 2000-2014 by the State Statistics Service of Ukraine and its regional divisions (Derzhavna sluzhba, 2020). Mathematical and statistical processing of the study results was performed by SPSS Statistics 17.0 software.

\section{Results and discussion}

At the initial stage of the task, population dynamics was analyzed (fig. 1) and the coefficients of paired linear correlation ( $r$ ) between the number of partridge and the key, in our opinion, environmental factors in Central Ukraine were calculated, which 
permitted to determine the field, intensity and statistical significance $(p)$ of the correlations between the factor and effective features (table 1).

The analysis of the birds number during the first 15 years of the XXI century testified to its moderately fluctuating type with a tendency to dynamic reduction from 2000 to 2007 (fig. 1). During the next 7-year period, there was a certain stabilization of the local population, which formed the lower plateau of indices within the range from 3.72 to 4.77 thousand individuals in 2007 and 2014, respectively. At that time, during the study period, the upper population plateau was not recorded at all, which also indirectly indicated a significant number of limiting environmental factors for this species in the region under study.

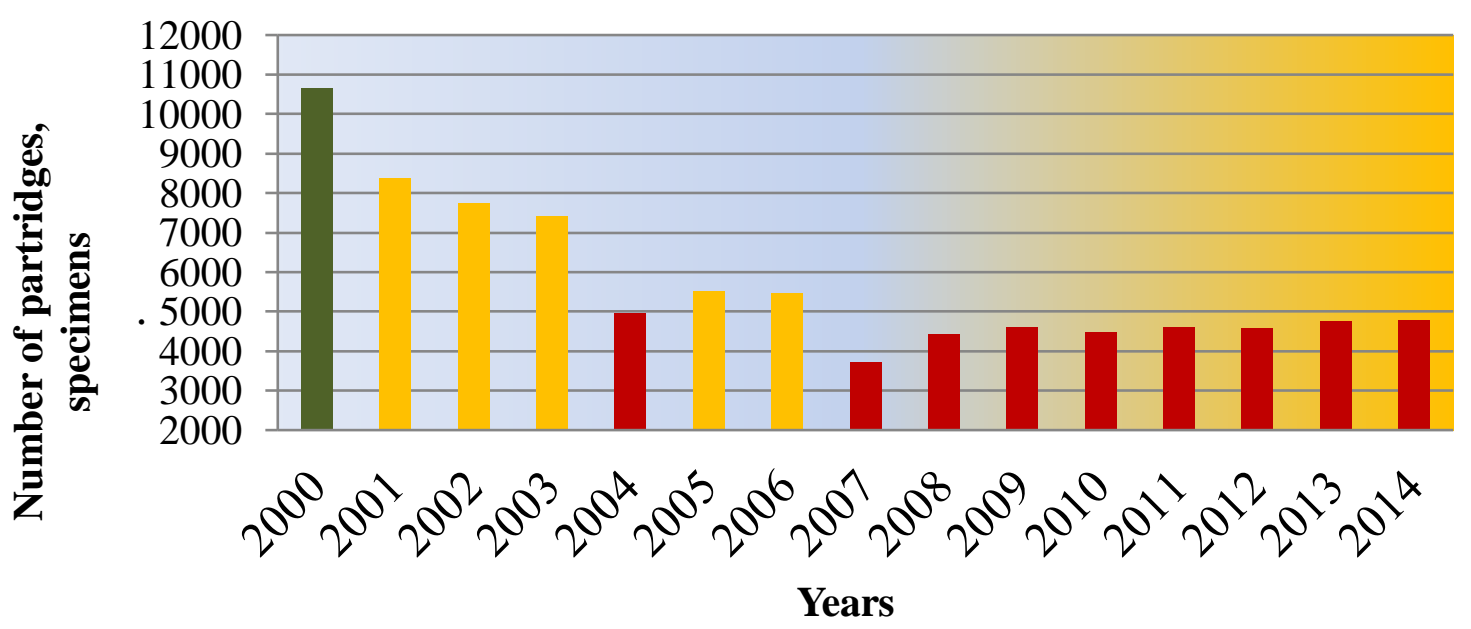

Fig.1. Population dynamics of the common partridge in Vinnytsia region, XXI century.

A 4-year cyclicity in changes of the local partridge cenopopulation dynamics was revealed. In general, 1-4 years of recession were followed by 1-2 years of relatively insignificant rise. It is worth noting, almost every subsequent peak did not reach the level of previous ones. The amplitude of fluctuations between the maximum (10.65 thousand specimens) and minimum ( 3.72 thousand specimens) values of the calculated birds in the regional lands was 6.94 thousand specimens, or $65.1 \%$ of the maximum. The mean density of birds in the lands during the study period was only $2.3 \pm 0.03$ specimens / thousand ha, with fluctuations from 5.3 to 1.8 specimens / thousand ha. The duration of the period between the maximum (2000) and minimum (2007) numbers was 7 years, and the mean number for the study period was $4.63 \pm 0.057$ thousand specimens in the total area of over 2017.6 thousand ha.

Table 1. Coefficients of pair linear correlation $(r)$ between the number of partridge and environmental factors

\section{Environmental factors}

Indices

Field-protective forest area, \% of ploughland

Common fox cenopopulation number, specimens.

Costs for biotechnical measures, UAH / thousand ha of hunting lands

Level of struggle against hunting violators, protocols units / thousand ha of lands

Level of struggle against agricultural rules violators, protocols units / thousand ha of lands

Planted areas, thousand ha:

Pulses

Soybeans

$-0.741$

Sunflower

Agriculture species

\section{sugar-beet}

annual grasses

perennial grasses

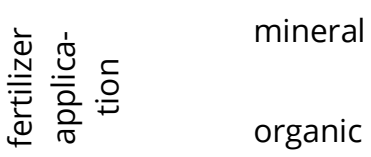

Rural population density, persons $/ \mathrm{km}^{2}$

Road density, km/thousand $\mathrm{km}^{2}$

In the study area, the indices of the common partridge cenopopulations number were not characterized by close correlations with the key climatic factors for the region, such as: average annual air temperature $(r=0.210)$, average winter air temperature $(r=0.436)$, average winter precipitation $(r=-0.394)$, average precipitation in June $(r=-0.447)$. 
Instead, a high mathematical degree of the common fox "carnivorism" was found here, with a density of this species in the range of $1.18-1.82$ specimens/thousand ha, compared to groups of partridges $(r=-0.957 ; p=0.05)$, as well as the positive effect of protective forest cover $(r=0.905 ; p=0.05)$. The latter should be explained by the enrichment of arable land with wild plants and the year-round availability of such fodder base, as well as by the formation of additional areas of reproduction and mitigation of the local microclimate in winter in general. The current weak ecological capacity of agricultural landscapes in Central Ukraine for common partridge can also be explained by the high dependence of the species' welfare on the level of biotechnical farming measures in the lands $(r=0.990 ; p=0.01)$. Mass poaching and non-compliance by farmers with agricultural standards are also, obviously, serious limiting factors for partridge in modern Ukraine, as can be seen from the data presented in the table.

It should be noted that the probable connection between the number of partridges and environmental factors of agricultural genesis was differently vectored. However, only $40 \%$ of them were severely limiting for the species. These were dominated by indices of areas under sunflower $(r=-0.802 ; p=0.1)$, areas $(r=-0.772)$ and rates of mineral fertilizers application $(r=-0.904 ; p$ $=0.05$ ). The significant difference in correlations between areas and rates of chemicals application emphasizes the harmful effect on the welfare of partridges rather of their concenrations than the processed areas, and leaves a wide front for further field, biochemical and statistical studies, including regression models. After all, in terms of a smaller percentage of limiting agricultural factors with account of their scale and potential harmfulness, we obviously obtain an absolutely shocking result, as in previous studies (Novytskyi, 2017).

The density of the rural population, as a marker indicator of the contour and phytocoenotic mosaic of agrolandscapes in Central Ukraine, is used by us not for the first time and once again confirms the positive influence of these factors $(r=0.946 ; p=0.05)$ on the formation of partridges population in lands. Instead, the paved roads density had naturally inverse $(r=-0.934 ; p=0.05)$ high correlations with the birds density. The latter, first of all, testifies to the unsatisfactory level of seasonal biotechnical measures in the region and is explained by the species' peculiarity of common partridges in the snowy period to accumulate near highways, where feeding is facilitated and rangles are available. As a result, partridges are more likely to be victimized by predatory animals and birds, stray domestic animals and car poachers.

\section{Conclusion}

Despite the favorable climatic conditions, agricultural landscapes of Central Ukraine are currently unsuitable for the successful existence of the common partridge. The density of birds here is currently critically low $\left(2.3 \pm 0.03 \mathrm{birds} / \mathrm{ha} 10^{3}\right)$ and requires implementation of global programs for protection, restoration and local reintroduction of the species. The main reasons for this situation are critical plowing of the region, low natural mosaic of arable land, monocropping, excessive chemicalization of arable lands, weak biotechnical measures and unsatisfactory natural fodder base in critical periods of the year. These circumstances dramatically constrict the range of nesting stations and feeding set of common partridge, forcing birds to concentrate in dangerous areas, which guarantee significant losses to the species from high levels of agricultural pressure, predation and poaching.

\section{References}

Derzhavna sluzhba statystyky. (2020). Available from: http://www.ukrstat.gov.ua/ (in Ukrainian)

Fedyushko, M.P., Gorbatenko, A.A., Gryb, O.G. (2011). Indykatory stanu asocijovanogo agrobioriznomanittya. Naukovi dopovidi NUBiP Ukrayiny, 5 (27), 14 (in Ukrainian)

Lakyn, G.F. (1990). Byometryya. Moscow. Vysshaya shkola (in Russian).

Novyczkyj, V.P. (2020). Myslyvski resursy agrolandshaftiv Ukrayiny: [stan ta problematyka upravlinnyam (na prykladi lisostepovoyi zony). Kyyiv, UkrDGRI (in Ukrainian)

Novytskyi, V.P., Mitay, I.S., Grishchenko, S.M. (2017). Habitat use of grey partridge in agricultural landscapes (the case of Ukrainian forest steppe). Ukrainian Journal of Ecology, 7(1), 58-60.

Pyrozhok, O. (2018). Povna degradaciya. Hto psuye ukrayinskyj chernozem. Available from: https://www.epravda.com.ua/publications/2018/06/4/637294/ (in Ukrainian)

Rudenko, F.A. (1986). Chyslennost seroj kuropatky, tendencyy y prychyn yzmenenyya. Vopros oxotnychej ornytologyy. Sb. nauch. trudov CzNYL RSFSR. Moscow (in Russian).

Ushkalenko, I.M. (2018). Analiz racionalnogo vykorystannya zemelnyx resursi u Vinnyczkij oblasti. Available from: http://www.economy.nayka.com.ua/pdf/12 2018/115.pdf (in Ukrainian)

\section{Citation:}

Novytskyi, V.P., Kondratiuk, V.M., Gruntkovskyi, M.S., Gryshchenko, S.M., Hryshchenko, N.P., Mytyay, I.S. (2020). Common partridge (Perdix perdix L.) in agrolandscapes of Central Ukraine: population dynamics and environmental implications.

Ukrainian Journal of Ecology, 106), 269-271.

\begin{tabular}{|l|l}
\hline$(\mathrm{cc}) \mathrm{EY}$ \\
\hline
\end{tabular} 